\title{
Lean Governance as a Condition for the Creation of Intellectual Coal Industry
}

\author{
Zaruba Natalyi A. ${ }^{a}$, Egorova Natalyi N. ${ }^{\mathrm{b}}$ \\ T. F. Gorbachev Kuzbass State Technical University \\ Kemerovo, Russian Federation \\ aznak42@mail.ru; begorovann@list.ru
}

\begin{abstract}
The article suggests the use of the concept of lean governance for formation of lean coal industry in the Kemerovo region, which may be relevant to a large coal region at the present stage of its socio-economic development. The Kuzbass coal basin is experiencing, like the entire coal industry in the world, not only the crisis but also the problem of overproduction of coal mining, the lack of demand in the market to the extent which is provided by modern technology in its coal production. Lean attitude to the coal resources as a source of economic growth in the coal region should be focused not on its volume and number, not on its removal from the region, but on its lean usage in the region and, above all, should be a matter of the quality of life of residents of the region, which may contribute to the experience of application of lean technologies in China, where the latter is included in the KPI (key performance indicators) to improve the efficiency of the coal industry. An important role in this should belong to the public administrations in the region focused on the application of lean technologies to make the Kemerovo region an economical coal region.
\end{abstract}

Keywords - lean coal industry, lean-technologies, Kaizen, 5s system, intelligent coal enterprise.

\section{INTRODUCTION}

The conversion of scientific and industrial potential of the country to the path of innovative development is defined as the main purpose of the state innovation policy of Russia at the present stage. The analysis of the current state of the coal industry indicates the development of different types of innovative clusters, including in the Kemerovo region. Technical and technological improvement of coal companies' activities is particularly relevant during the crisis. According to experts, the emergence of the newest technological structure will make the coal industry attractive to investors who go out of outdated coal plants actively now. We are impressed by the opinion of some experts, who believe that "today to gain a competitive advantage is possible only through the introduction of new technologies, implementation of innovations based on the use of new scientific solutions and attraction of young and energetic skilled workers" [1]. The researchers rightly point out that innovation in the coal industry, in general, is focused on promising areas of its development: the gradual improvement of the financial situation of coal companies and the formation of economic conditions for the development of production; the creation of a competitive coal market and positive technical change and economic level of coal production; realization of priority directions of development of science, technique and technologies, as well as access to high-quality end products, including in the framework of coal, energy coal and metallurgical complexes [1].

Analysis of practice of realization of innovations at the enterprises of the region's coal industry that was conducted by researchers shows that innovative activity is due to a variety of directions. Among these directions there is joining, in a number of cases, of all enterprises for mining and coal processing, systematic preparation for excavation of coal reserves and the implementation of new mine field systems; development of coal seams with the highest quality reserves, economically profitable for coal extraction; increase in labor productivity on the basis of the concentration of mining and technical re-equipment of production; increase in the safety and efficiency of technical production; changes in the design and technology of mine workings supporting; implementation of complete conveying in the intra-mine transport; personnel skills development and improvement. [1].

However, without prejudice to the merits of proposed science upgrade paths of the coal industry, it should be noted that it is necessary to pay attention to the underestimation of the role and the values of management of the state and local governments, for example, in the innovative development of the coal industry. Relevance of the research of new technologies in governance at all levels is evident, especially in the present conditions of the search for optimal ways of Russia's withdrawal from the economic crisis, and above all, to bring out of the deep crisis of weak economic update and developing territories. Management in this case should be seen as a condition and as a lever to address this kind of problem.

As a modern control technology, we think we can offer a lean management technology, actively developing in the world, including China, and that attracts the attention of a number of Russian scientists, both in the economy and in public administration.

Scientific novelty of research, the basic points of which are presented in the article, is that 
- the urgency of a lean governance concept is proved in terms of socio-economic crisis in the world in order to increase the efficiency of the coal industry, the creation of lean coal industry, lean region, lean enterprise, etc .;

- the need for logistics planning of lean management process is showed, which is a set of sequential steps: mapping and visualization of current management; measurement and analysis of the current state of the elements of the management; creation and mapping of new management model; performance evaluation and development of actions for the implementation of the new management process;

- a model of "lean governance" and the concept of "lean region" is offered, which includes the following main elements: the visualization of control processes in the region, the involvement of all stakeholders (management structure and coal mines) in the conduct of rational action to improve production efficiency; mapping (schematic representation) of the process of interaction of the regional management of the coal industry; losses in carrying out the process; elimination of waste; methods of lean technologies for the coal industry; teaching lean technology at coal plants;

- the idea of establishing an international center or institute of lean governance is proposed through the integration of research achievements of China and Russia.

The logic of the research process, aimed at the development of the concept of lean state management, consistently relying on the analysis of information sources on the lean-technologies allowed the authors to prove the effectiveness of their use in the coal industry.

\section{DISCUSSION}

The theoretical basis for further research in the science of the control technology allows us to speak about its viability and progressiveness. The term "lean production" appeared in the early 90 -ies of the last century, it was introduced in scientific literature by the American scientist John Krafchik in the article "Triumph of the lean production system." Basically, it emphasizes the combination of the scientific organization of labor, a new production management system and methods of labor quality management, introduced by the Japanese company "Toyota". In his works, Krafchik says: "Lean production - this system contributes to the comprehensive development and integration of all existing resources that traditional policies do not seem to notice" [2]. We found it interesting to review the study of using "lean technologies" problems implemented by such scientists as: M. Porter, W. Levinson, Jeffrey L., O. Vikhansky, M.N. Dudin, V.G. Ignatov interesting.

In the early 2000s, another American scientist M.L. George supplemented the concept of "lean production" by the principles of the concept of "six sigma", based on the following directions:
- stability and forecasting the process, in this case, of public administration and local government;

- analysis and accountability, as well as the ability to measure and change the process parameters;

- proactive management;

- openness and transparency of the process;

- continuous improvement of the process (kaizen) [3].

It is alleged that the lean technology is nothing less than quality, built-in process that allows you to optimize resources and increase production efficiency, business management. It should be noted that the concept of lean-technologies, thanks to this approach, is already widely applied in almost all areas (manufacturing and non-manufacturing). The practice of its application in improving the activities of state authorities and local governments creates a great interest.

However, analysis of the practical application of lean techniques showed that over the past 10 years, they received the most widespread application abroad in the state and local self-government in such countries as the USA and Japan. So, in the United States such states as Michigan, Colorado, Iowa, Oregon apply the basic principles of "lean state", in particular, the identification and elimination of losses in the management process [3].

In Russia, the problem of the use of lean-technologies has been discussed since 2006, for the first time on the first Russian Lean Forum "Lean Production for Russia" in the city of Yekaterinburg. Further annual forums indicate a growing interest in the concept of lean technologies. The researchers note that using this technology it is possible to design a new vector of economic growth, [4] putting the principles of "lean governance" at the forefront. With that, we think, that it is possible both in production and in the sphere of public administration and local self-government.

It is important to note that the analysis of the literature points to the urgency of improving governance through the use of new control technologies. [5, 6, 7, 8, etc.]

A discussion of the problems of the "lean state" at the Lean forums in Russia today contributes to the solution of many administrative issues to optimize the budgets of different levels, the growth of GDP and GRP, and can become a trigger mechanism for the implementation of lean technologies in the coal business, and in government. It should be noted that the pioneers of the concept of lean-technologies in Russia are such organizations as: Evraz, Eurochem, Rusal, Sberbank, today the practice of "lean manufacturing" is implement by many Russian enterprises and organizations. The experience of the application of "lean governance" at the state level and the municipal government should be noted too. So it is successfully implemented in Tatarstan, and the brand "lean city" is assigned to such Russian cities as Kazan, Naberezhnye Chelny. The term "lean region" is used today to Yugra, which is already in the running for the regional level, introducing "lean-technology." 
In our view, this technology is poorly understood and may be required more broadly in terms of economic and technological crises, for example in the whole region or the whole industry. For example, a particularly vulnerable during the economic crisis of old-industrial regions with a monoeconomy, such as the Kemerovo region, may be interested in the implementation and development of lean management technologies. The Kemerovo region, currently continues to be an industrial region with a predominance in the sectoral structure of the economy of heavy industries, such as mining. [9]

The coal industry (due to the availability of raw materials) historically holds a key position within the development of the region and its socio-economic stability. Nowadays, the Kemerovo region is the leader in the SFD (Siberian Federal District) in coal production accounting for $71 \%$ of the total volume in the Siberian region and $61 \%$ in the Russian Federation. In the sectoral structure of the region, coal industry is dominant (the proportion of $31.4 \%$ ) and, accordingly, it is the main source of GRP and replenishment of the budget.
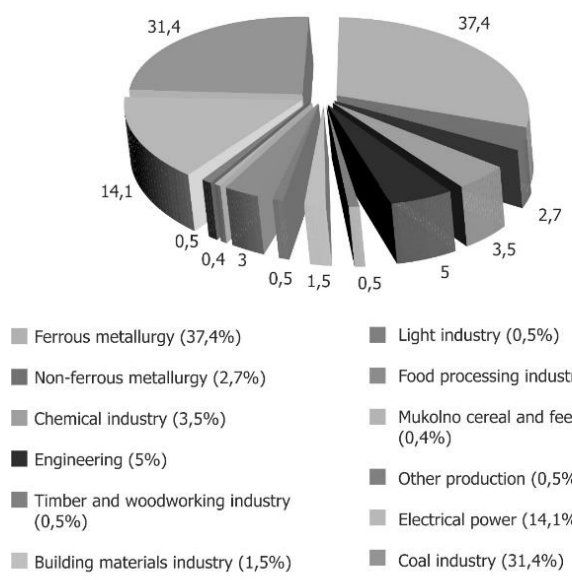

$$
\begin{aligned}
& \text { Light industry }(0,5 \%) \\
& \text { Food processing industry }(3 \%) \\
& \text { Mukolno cereal and feed mill industry } \\
& (0,4 \%) \\
& \text { Other production }(0,5 \%) \\
& \text { Electrical power }(14,1 \%) \\
& \text { Coal industry }(31,4 \%)
\end{aligned}
$$

Fig.1. The structure of the economy of the Kemerovo region

Related industries such as ferrous and non-ferrous metals also occupy dominant positions in the total industry, and together account for about $40 \%$, as a result, we have $70 \%$ of production directly related to the extraction of coal in the structure of the economy (Figure 1) [10].

It should be noted that in the last 7 months of 2014 production volumes increased slightly compared with 2013 year (by $0.8 \%$ ) and amounted to 215 million tons in volume terms, production of coking coal is similar - in 2014 it amounted to 31 million tons, and increased by $1.6 \%$. [10]. In addition, we consider it important to emphasize that the coal enterprises of the Kemerovo region are town-forming in all the major municipalities in the region, which once again highlights the importance of the coal industry (Figure 2).
However, the dynamics of the GRP in the economic activity for 2010-2014 years has a tendency to a slight decrease compared to the previous period, mining operations during the analyzed period have also been reduced by $25 \%$ (Figure 3).
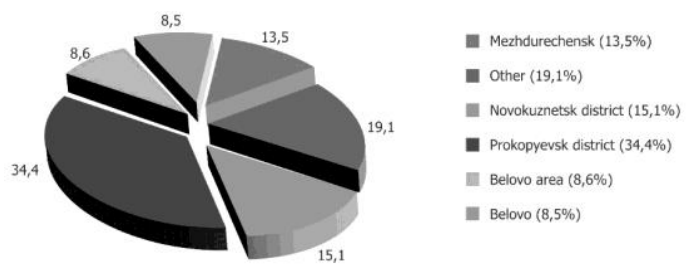

Fig. 2 The structure of municipalities of the Kemerovo region

This trend underlines the growing problems of coal branch of the Kemerovo region and the need to address them, including, by the application of new management technologies in public administration as well, since the deterioration of the performance of the enterprises of the coal industry remains for a long time continuing to reduce replenishment of the budget of the region by reducing the tax payments. In addition, the coal industry in 2015 had overdue accounts payable in the amount of $93,375 \mathrm{mln}$. rubles, of which 60,163 - to suppliers, $4.111 \mathrm{mln}$. rub. - to the budgets of all levels, including regional and $3.186 \mathrm{mln}$. rubles - to pay to the state off-budget funds. [11]

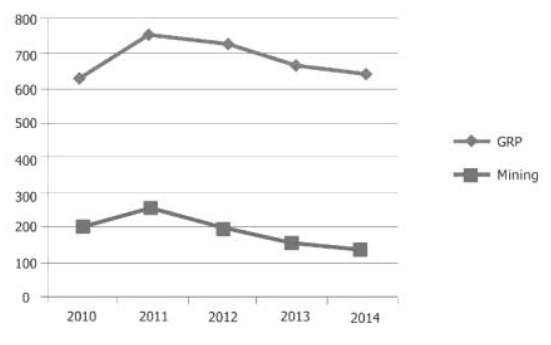

Fig.3 The dynamics of GRP and coal mining in the Kemerovo region for 2010-2014

The debts of the enterprises only confirm the problems of coal branch of the Kemerovo region. The problems of the coal industry are now becoming an obstacle to the development of the region as a whole, given according to the data presented the role and importance of the coal industry for the region.

At the same time it should be noted that they are trying to decide on a more prudent use of its main resource - coal in the region. For example, the establishment of an innovation cluster for complex processing of coal and processing waste should be directed, in our opinion, on the lean coal production process.

The enterprises of the Kemerovo coal-chemical cluster employ $2 \%$ of the working population of the region, the planned result of their activity is more than 100 coal-chemical products. But this production can not be achieved without the 
use of lean governance techniques, with that in principle, at all levels: national, sectoral, municipal government agencies and the particular coal enterprise.

At the same time, we should pay attention to the similarity of the problems in the coal industry in China with our difficulties, it is now also subjected to the process of bifurcation. Since 2014, there is practically no increase in coal consumption due to the reformation of the structure of industry in favor of less energy-intensive technologies, with a decrease in its own coal production by $3 \%$, despite the stagnation of demand in 2013-2014 years. [12]

Carrying out coal gasification, its conversion, reduction of transport costs, involvement in the production of cheaper and lower-quality brands, such as lignite (brown coal), all the above testifies that the use of coal resources in China is already more efficient with regard to the principles of lean production and consequently the whole concept of lean governance [12].

One cannot ignore China's experience in innovative technological approach to solving tasks, including the tasks faced by enterprises of the coal industry [13, 14]. It is necessary to note the presence of the problems of current search for technologies in the coal industry and in the AsiaPacific region, many of which in an increasingly competitive environment can be solved primarily by the innovative development of the coal industry of the Far East. Kuzbass scientists also make attempts to solve the problems of the coal industry through the use of innovative technologies [15].

\section{RESULTS}

Therefore, further development and implementation of models of "lean governance", at the state and municipal levels, may become an important aspect of the solution to these problems in Russia in accordance with modern requirements for the operation of the coal industry in the Kemerovo region as mono - regional coal orientation, which has the following features today:

- high cost of coal freight transportation, including due to the growth of railway tariffs;

- unused possibilities of commissioning of new production facilities;

- the need to increase the efficiency of coal production;

- incompatibility between the volume of coal production and its quality;

- untimely correlation of the information on coal production and coal preparation;

- the lack of deep coal processing programs;

- reduction of coal production costs;

-reduction of the impact of human factors over the entire chain of coal production process;

- the absence of a closed type technology to reduce the impact on the ecology of the region

- ensuring industrial safety in enterprises;

- coordination of activities within the company and in interaction with environmental factors, including regional management structures; -lack of on-line information support of the manufacturing process [16].

Designated features should be considered as a kind of "obstacles", as losses, for the development of the coal industry, which can be eliminated, in our opinion, due to the development of the so-called "lean governance technologies", which should be used as a condition of productivity growth, the formation of an "intelligent " mining company and others.

It should be noted that the development and implementation of the concept of "lean governance" in relation to the coal regions can contribute to a "lean coal region," "lean coal mine." The basis of the concept of "lean governance" in relation to the coal region, that is actively carrying out the search for yield, especially from the process of the crisis of the coal industry, we regard it expedient to consider the evolving science concept of lean governance technologies applied to government and industry management as an important condition for the development of the region and industry.

It is important to emphasize the attention paid to the use of the concept of lean technologies in public administration by the Russian government. Russian Prime Minister Dmitry Medvedev outlined the importance of its application: "Improving the efficiency of public administration should be carried out through the use of new management techniques, as it is happening today in the world. Many of them such as a project management and performance management, and the so-called lean-technologies came out of the business and are successfully used there."[17]

However, it should be recognized that, in spite of some attempts already made to study and put into practice the concept of lean technologies in the economy and in the government is acquiring only the first steps, such as Yugra - a Russia's region.

We believe that the Kemerovo region in the development and implementation of the concept of "lean region" based on the lean model of management is also able to achieve the objective of development of this technology in public administration. The lean management concept is oriented on the development of internal regional features of the Kemerovo region, on the effective use of funds of the regional budget and its timely completion, at a deeper solution to the problems of the coal industry in the region by identifying missed opportunities, research gaps and loss of control or production process. Minimization of losses that the company or the authorities are trying to achieve by any means is a condition and a lever for the development of the state, industry, the region in crisis.

Such a conclusion can be drawn, based on the overview of the practice of lean technologies in the world and in Russia. Moreover, this conclusion allows to reach the main informative tools of this concept, particularly the application of the model of rapid and systemic improvements, reducing the complexity of processes, measurement and visualization of process performance that is particularly difficult and necessary in the public administration and local governments. 
It is important, in our view, to identify the specific features of processes used in the management of the region, which point to the prospect of applying the following lean management technologies:

- cross-cutting (cross - functional) nature of management processes;

- high variability of processes;

- the high level of the inspection process and as a consequence of the rising cost of services and the increase in the duration of their performance;

- the absence of the metric system to control processes;

- lack of knowledge and information on lean-management and consequently a distrust to the implementation of lean management technologies.

As already mentioned, the concept of lean production is a systematic procedure to locate and correct different kinds of losses that, in our opinion, have a place in the system of public administration in the region in the coal industry of the region: it is the loss in the economy, ecology, environmental management etc.

To identify and eliminate losses in order to improve the activities of organizations and companies, the techniques such as kaizen events, 5S, mapping of individual processes, mapping the value chain as a whole, visual management [18] are mostly used.

Z. Radnor and S.P. Osborn note that lean management technologies are used for three purposes: first, the evaluation process of the services at the organizational level; secondly, the maintenance of a steady state process and improvement; thirdly, monitoring $[19,20]$.

It is thought that these methods are applicable to coal and regional management process, and the coal industry and coal enterprises, since the losses are everywhere and, above all, in the process, from coal production to deep processing. In our opinion, for example, a combination of methods of "Six Sigma" and the concept of "lean governance" will allow to solve many problems that have accumulated in the region more efficiently: its technologizing, modernization, diversification, and others.

The necessity of logistics planning of the management process, which naturally was recorded schematically in the form of a gradual process of "lean governance" was proved in the course of study (Fig. 4).

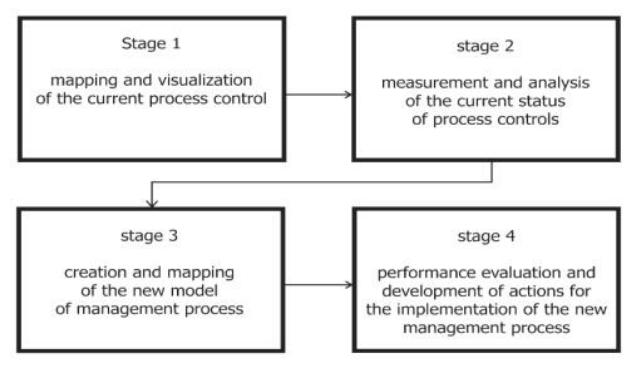

Fig. 4 Main stages of lean state management in the region.
On the basis of the scheme proposed by the authors a model of "lean governance" under the concept of "lean region," which includes the following key elements embodied in the proposed formula has been developed:

$$
M L S M=V+I^{\prime}+M P+(L O-E L)+M+T R L T
$$

where:

$V-$ visualization of control processes in the region;

$I^{y}-$ involvement of all stakeholders (management structure and coal mines) in the conduct of rational action to improve production efficiency;

$M P$ - mapping (schematic representation) of the process of interaction of the regional management of the coal industry;

$L O$ - losses in carrying out the process;

$E L$ - elimination of losses

M - methods of lean technologies for the coal industry;

TRLT - training in lean technology at coal plants (or the establishment of the Centre or the Institute of lean management at the regional level).

\section{CONCLUSION}

We would consider it appropriate to create a Centre or Institute of Lean governance for the research and scientific basis of the effective implementation of "lean governance" concept, together with the PRC in the Kemerovo region. The study and implementation of technologies of "lean production" and "lean management" will contribute to the transfer of coal enterprises in the region in the area of development of "intelligent coal mine" that can predict the strategic new technological supply chain, not only for coal mining, but also its deep processing without large losses and omissions. This, in its turn, can contribute to increased efficiency and productivity, increased tax collection and updating of regional and federal budgets. Designated steps of lean state management in the coal region, for example in the Kemerovo region, will enable in the most reasonable way to predict from the starting point of the coal mining process the required future volumes of coal resource, the quality, delivery times, the possibility of processing within the region, ensuring its more effective use, as well as identification of possible losses and their prevention.

In our opinion, it is the deep processing of coal, as the implementation of "lean technology" concept, should be one of the primary tasks for the Kemerovo region, which will be able to forward the coal industry of the region on innovative development track. Thus, in order to develop the Kemerovo region in the above direction, the traditional management methods of public administration are not acceptable, since instead of being the lever and an important prerequisite, they will be the brake and an obstacle. The public administration must become lean too. 


\section{REFERENCES}

[1] Zaruba N.A., Kostyuk S.G. Problems of engineers' training in the conditions of innovative development of economy // in the collection: Problems of continuing education: design, management, operation: Materials of the X International scientific-practical conference. Lipetsk, 2012. pp 206-213.

[2] John Krafcik. "Triumph of the Lean Production System" MIT Sloan Management Review (SMR)1988. - url: http://www.lean.org/downloads/MITSloan.pdf (data 20.04.2016)

[3] Michael J.. Lean production + Six Sigma. By combining Six Sigma quality with lean speed production. M. Alpina Pablisher.2007.

[4] Savkova E. Lean Philosophy - a modern approach to resource conservation in the development of marketing strategies // Marketing. Ideas and technology. 2008. \# 6.pp 14-20.

[5] Zaruba N.A, Shebukova A.S. Economic education of students of the specialty "State and municipal management": problems and ways of their solution // Bulletin of the Kuzbass State Technical University. 2015. \# 2 (108). pp 163-166.

[6] Zaynutdinov R.R. Single-industry regions of Russia: definition, typology and development prospects // The economy of the region: Publisher: Institute of Economics of the Ural Branch of the Russian Academy of Sciences ISSN: 2072-6414. 2015. \# 4 (44) pp.106-122.

[7] Rastvortseva S. N. Theoretical bases of regional development efficiency management// The region's economy: Publisher: Institute of Economics of the Ural branch of the RUSSIAN ACADEMY of SCIENCES ISSN: 2072-6414 2008. \# 2. pp. 241-246.

[8] Zaruba N.A., Kozhevnikova A.V. Corporate specialist training as a factor in improving the functioning of the municipal educational institution // Vestnik Kuzbass.gos. texn. yniv.. 2014. \# 1 pp 177-180.

[9] Egorova N.N. The role of the diversification of the regional policy in the management of economic development of the Kemerovo Region // Innovative Economy: Prospects for development and improvement. 2014. \# 1 (4), pp 234-237.

[10] Statistical Yearbook. Businesses and organizations - url: http://kemerovostat.gks.ru(data 20.04.2016).
[11] Social and economic situation of the Kemerovo region - url: http://kemerovostat.gks.ru(data 20.04.2016).

[12] Second Wind of China coal industry. Why large-scale coal gasification is a "nightmare" for the West - url: http://www.odnako.org/blogs/vtoroedihanie-ugolnoy-otrasli-knr-pochemu-masshtabnaya-gazifikaciya-uglyastrashniy-son-dlya-zapada(data 20.04.2016).

[13] Valtteri Kaartemo, Kari Liuhto Technology-Innovative Special Economic Zones in Russia: Lessons from China // Forsyth, IZD-vo: National Research University "Economics". ISSN: 1995-459X. 2010 vol. 4 \#. 2. pp. 18-25

[14] Xielin Liu, Nannan LundinChina: Toward a Market-based Open Innovation System // Forsyth, Publisher: National Research University "Economics" ISSN: 1995-459X. 2007. vol. 1, \#. 4. pp. 20-31

[15] Kolesnikov V.F., Chikishev I.A Features of formation of cargo flows on coal mines of the Southern Kuzbass // Vestnik Kuzbass.gos. texn. yniv 2012. - № 4. - pp. 26-28.

[16] Review of coal industry - url: http://dok.opredelim.com/docs/index22151.html(data 20.04.2016).

[17] Plenary session of the World Economic Forum "Russian Development Scenarios" in Davos http: http://archive.government.ru/special/docs/22496/(data 20.04.2016).

[18] Furterer S., Elshennawy A.K. Op. cit.; Lean Government Methods Guide // United States Environment Protection Agency, 2013. URL: http://leangovcenter.com/Pdf/EPA\%20lean-methods-guide\%5b1\%5d.pdf (10.05.2014).

[19].Radnor, ZJ and Osborne SP Operationalising lean in services: Rediscovering service blueprinting. In Public Service Operations Management: A Research Handbook, pp.294-309, ISBN: 9781138813694-

url: http://www.paulallen.ca/documents/2015/08/osborne-sp-z-radnor-i-vidaland-t-kinder-a-sustainable-business-model-for-public-serviceorganizations-2014 (data 20.04.2016).

[20]. Kuznetsova G. A. The appreciation methodology of innovation development parameters of the coal industry in the Far East region increased competition on the market of the Asia-Pacific// The region's economy: Publisher: Institute of Economics of the Ural branch of the RUSSIAN ACADEMY of SCIENCES ISSN: 2072-6414. 2010. \# 3. P. 138-143. 